\title{
ПОШИРЕНІСТЬ АЛІМЕНТАРНОГО ОЖИРІННЯ У ХВОРИХ НА ПОДАГРУ
}

\author{
I. Р. Маселко, О. В. Прокопчук, С. В. Даньчак \\ КЗ “Самбірська центральна районна лікарня" \\ ДВНЗ «Тернопільський державний медичний університет \\ імені І. Я. Горбачевського МОЗ Украӥни"
}

У статті висвітлено особливості частоти виявлення аліментарного ожиріння у хворих на подагру та актуальність вивчення цього питання.

\section{PREVALENCE OF ALIMENTARY OBESITY IN PATIENTS WITH GOUT}

\author{
I. R. Maselko, O. V. Prokopchuk, S. V. Danchak \\ Sambir Central District Hospital \\ I. Horbachevsky Ternopil State Medical University
}

The article highlights features of alimentary obesity in patients with gout and relevance of research of it.

Вступ. Захворювання кістково-м'язової системи мають важливе медико-соціальне значення, оскільки $\epsilon$ одними з найпоширеніших патологій сучасності. Значною мірою серед них переважають атропатії. Подагричний артрит є розповсюдженою патологією і вважається найпоширенішим запальним захворюванням суглобів у мужчин. В індустріалізованих країнах світу на подагру хворіє щонайменше 1-2 \% населення [1]. У літературі достатньо висвітлено різні проблеми в якості коморбідних станів у хворих із патологією опорно-рухового апарату, зокрема при подагрі, та актуальним залишається вивчення проблеми наявності ожиріння у них, оскільки це не лише обмежує працездатність, але й значно погіршує якість життя хворих.

Основна частина. Подагра $\epsilon$ хронічним прогресуючим захворюванням, яке пов'язане з порушенням пуринового обміну та характеризується підвищенням рівня сечової кислоти в крові (гіперурикемією) і відкладенням у тканинах опорно-рухового апарату та внутрішніх органах натрієвої солі сечової кислоти (уратів) із розвитком гострого артриту та утворенням подагричних вузликів (тофусів) [2-4]. На сьогодні подагра $\epsilon$ найпоширенішою патологією суглобів у працездатних чоловіків, що становить 0,3% від загальної захворюваності [5-7].

Проблема подагри вивчалась науковцями багатьох поколінь і перші літературні посилання з'явились ще () І. Р. Маселко, О. В. Прокопчук, С. В. Даньчак, 2018 в XIII-XIV століттях, вивчення цієї патології та її поєднаних станів залишається актуальним і на даний час [8-10].

Дослідження останніх років підтвердили швидкі темпи зростання частоти подагри [11]. За даними епідеміологічних досліджень, близько 0,01-0,37 \% дорослого населення страждають від подагри, хоча і в цих випадках наявна ії різна частота в світовій популяції [12]. Окрім цього, існують регіональні особливості [13].

Багато вчених протягом останніх років посилено займаються вивченням подагри та їі сучасного перебігу [14]. Неодноразово висвітлювався широкий спектр питань, присвячених особливостям клінічної діагностики, профілактики та лікування цього захворювання.

У 2008 р. було встановлено, що поширеність вперше виявлених випадків подагри в США становить 2-3 млн пацієнтів серед дорослого населення. Так, результати наукових досліджень на основі зведення багатьох баз даних припускають, що показники поширеності збільшилися за останній період, особливо серед людей літнього віку (понад 65 років) [15]. Численні дослідження, проведені у Великій Британії, показали, що поширеність подагри, при якій не проводилась медикаментозна корекція, становить 1,4%. Друге та четверте дослідження національної захворюваності у Великій Британії показали, що показники поширеності подагри збільшились у 3 рази. У дослідженні з використанням великої бази даних досліджень із загальної медичної практики поширеність

30 ISSN 2411-1597. МЕДСЕСТРИНСТВО. 2018. № 1 
подагри, що не підлягала медикаментозній корекції, становила 1,4 \%, при цьому найвищий показник у 7,3 \% спостерігали у чоловіків віком від 75 до 84 роки. Пізніше дослідження в Німеччині та Великій Британії показали, що поширеність подагри становить 1,4% в обох країнах за період з 2000 до 2005 р. [16].

Італійські науковці провели дослідження з метою встановлення епідеміологічних особливостей подагри свого населення. Встановлено, що з 2005 до 2009 р. поширеність подагри збільшилась від 6,7 до 9,1 випадку на 1000 населення. Крім цього, виявлена більша частота захворюваності у чоловіків порівняно із жінками (співвідношення 4 : 1) [17].

Загалом поширеність подагри в Європі становить у дорослого населення 1-2 \%, а в осіб старше 50 років - $6 \%$.

В Україні, в свою чергу, поширеність подагри становить 0,4 \% дорослого населення [18]. Пік захворюваності в чоловіків припадає на вік 35-50 років, у жінок - 55-70 років [19]. Прогностично несприятливим вважається розвиток хвороби у віці до 30 років [3].

Імовірно такі коливання показників пов'язані 3 відповідно різним рівнем життя населення, особливостями харчування, хронічним вживанням алкоголю, неконтрольованим прийманням лікарських препаратів [20].

$€$ багато захворювань, які виступають в якості супутніх станів при подагрі (гіперліпідемія, артеріальна гіпертензія, цукровий діабет 2 типу), але найбільш частим коморбідним вважається ожиріння.

За даними ВООЗ, ожиріння є епідемією XXI століття. Саме надмірна маса тіла та ожиріння є найпоширенішими проблемами сучасного населення. Збільшення маси тіла набуло епідемічного поширення та виявляють у близько 30 \% населення Європейського регіону.

Окрім цього, існує гіпотеза, згідно з якою центральний тип ожиріння є причиною інсулінорезистентності, гіперінсулінемії та інших метаболічних порушень [21]. Також ожиріння є одним із незалежних факторів ризику розвитку подагри у пацієнтів із асимптоматичною гіперурикемією, оскільки при ожирінні не тільки знижується ниркова екскреція уратів, але значною мірою зростає і їх продукція, підвищуючи цим віро-

\section{СПИСОК ЛІТЕРАТУРИ}

1. Джанашия П. Х. Является ли гиперурикемия компонентом метаболического синдрома? / П. Х. Джанашия, В. А. Дибенко // Российский кардиологический журнал. 2002. - № 1. - C. 15-17. гідність розвитку подагри більше ніж у 3 рази. Ці та інші фактори визначають актуальність вивчення його наявності у подагричних хворих із метою корекції не лише лікування, а насамперед способу життя, оскільки в сучасному світі все сприяє тому аби полегшити всі сфери життєдіяльності, зменшуючи цим самим активність, фізичні навантаження та інші речі, які роблять людей малорухливими.

Для досягнення мети вивчення проблеми наявності та поширеності ожиріння у хворих на подагру було обстежено 70 хворих за допомогою методів опитування, огляду, оцінювання антропометричних параметрів: маси тіла, зросту та визначання індексу маси тіла (IMT).

Для визначення наявності та ступеня ожиріння використовували індекс Кетле або ж ІМТ, який $є$ показником, що визначає збільшення в людини маси тіла та ожиріння за допомогою розрахунку пропорційності маси тіла до зросту. Його ми вираховували за допомогою формули: IMT = маса (кг)/зріст $\left(\mathrm{M}^{2}\right)$. Оптимальним слід вважати значення IMT у межах

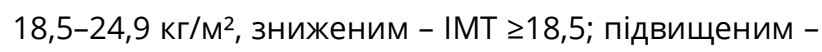
$\geq 25,0$; передожиріння - 25,0-29,9; ожиріння І ступеня 30,0-34,9; ожиріння II ступеня - 35,0-39,9; ожиріння III ступеня - $\geq 40$ (кг/м²).

Аналіз отриманих даних свідчить, що середній вік хворих - $(46 \pm 0,16)$ року. При обстеженні встановлено, що за індексом маси тіла спостерігали такі зміни: з нормальною масою тіла було лише 9 \% хворих, з надмірною масою тіла налічували 20 \% пацієнтів, ожиріння І ступеня було наявне у $41 \%$, ожирінням II ступеня - у 22 \%, з ожирінням III ступеня було 8 \% хворих.

Висновки. Ожиріння різного ступеня виявлено у $91 \%$ хворих на подагру, що варто враховувати не лише при виборі тактики лікування, але й у призначенні відповідного дієтичного харчування та у рекомендаціях стосовно способу життя. Медичні працівники повинні активно займатись пропагандою здорового збалансованого харчування не лише у стінах лікувальних закладів, але наголошувати, що це все має мати місце і поза ними, оскільки лікувальний процес забезпечується не лише медикаментозними засобами, але й веденням правильного та активного способу життя.

2. Долженко М. Н. Липидный дистресс-синдром или новое - это хорошо забытое старое? / М. Н. Долженко // Мистецтво лікування. - 2006. - № 7. - С. 28-31.

3. Арьев А. Л. Подагра / А. Л. Арьев. - СПб. : СПбМАПО, 2009. - 109 c. 
4. Reaven G. M. Insulin resistance/compensatory hyperinsulinemia, essential hypertension, and cardiovascular disease / G. M. Reaven // J. Clin. Endocrinol. Metab. - 2003. Vol. 88. - P. 2399-2403

5. Дисбиоз: современные возможности профилактики и лечения / В. М. Бондаренко, В. Ф. Учайкин, А. О. Мурашова [и др.]. - М., 1995. - 68 с.

6. Arromdee E. Epidemiology of Gout: Is the Incidence Rising? / E. Arromdee, C. J. Michet, C. S. Crowson // J. Rheumatol. - 2005. - No. 29. - P. 2403-2406.

7. Epidemiology of gout and hyperuricemia in Italy during the years 2005-2009: a nationwide population-based study / G. Trifiro, P. Morabito, L. Cavagna [et al.] // Ann. Rheum. Dis. - 2013. - Vol. 72. - P. 694-700

8. Проценко Г. О. Моніторинг тривалого лікування хворих на подагру / Г. О. Проценко, Н. С. Бойчук // Укр. ревматол. журн. - 2007. - № 4. - С. 30-33.

9. Проценко Г. О. Особливості перебігу подагри у жінок / Г.О. Проценко // Вісник наукових досліджень. - Тернопіль : Укрмедкнига. - 2008. - № 3. - С. 18-21.

10. Казимирко В. К. Ревматология : учебное пособие для врачей в вопросах и ответах / В. К. Казимирко, В. Н. Коваленко. - К., 2009. - 626 с.

11. Dalbeth N. Hyperuricaemia and gout: state of the art and future perspectives / N. Dalbeth, A. So // Ann. Rheum. Dis. - 2010. - Vol. 9 (10). - P. 1738-1743.

12. Насонова В. А. Современное учение о подагре. В помощь практикующему врачу / В. А. Насонова, В. Г. Барскова // Здоров'я України. - 2005. - С. 129.
13. Increasing prevalence of gout and hyperuricemia over 10 years among older adult in a managed care population / K. L. Wallace, A. A. Riedel, N. Joseph-Ridge [et al.] // J. Rheumatol. - 2004. - No. 31. - P. 1582-1587.

14. Stamp, L. K. Gout and its comorbidities: implications for therapy / L. K. Stamp, P. T. Chapman // Rheumatology. 2013. - No. 52 (1). - P. 34-44.

15. Prevalence of gout and hyperuricemia in the US general population:the National Health and Nutrition Examination Survey 2007-2008 Arthritis Rheum. - 2011. - Vol. 63 (10). P. 3136-3141

16. Annemans L. Gout in the UK and Germany: prevalence, comorbidities and management in general practice 20002005 / L. Annemans, E. Spaepen // Ann. Reum. Dis. - 2008. Vol. 67. - P. 960-966.

17. Prevalence and incidence of gout in Italy. Analysis of a primary care database / L. Cavagna, G. Trifirò, R. Caporali [et al.] // Ann. Rheum. Dis. - 2012. - Vol. 71 (13). - P. 721.

18. Мороз Г. З. Подагра: сучасні підходи до діагностики та лікування / Г. З. Мороз // Therapia. - 2010. - № 7-8 (49).

19. Ревматичні хвороби та синдроми / А. С. Свінціцький, О. Б. Яременко, О. Г. Пузанова, Н. І. Хомченкова. - К. : Книга-плюс, 2006. - 680 с.

20. Синяченко О. В. Метаболический синдром у больных подагрой / О. В. Синяченко, Т. В. Мягкова, Г. А. Игнатенко // Врачебная практика. - 2006. - № 2. C. 50-55.

21. Dalbeth N. Hyperuricaemia and gout: time for a new staging system? / N. Dalbeth, L. Stamp // Annals of the Rheumatic Diseases, Annrheumdis. - 2014. 